\title{
Corporate Governance In Relation To The Enhancement Of Social Responsibility
}

Matej Lahovnik, University of Ljubljana, Slovenia

\begin{abstract}
Paper argues that managers have the obligation to make choices and take actions that will contribute to the welfare and interests of society as well as the organisation. Social responsible behaviour is actually in a company's self interest. Therefore the company must take the social consequences into account when formulating strategies. Still there are those scholars who argue that considerations of social responsibility should not enter into the decision process. However, many institutional investors pay attention to corporate social behaviour and thus influence the market for a company's stock. Our conclusions are based on a longitudinal research method. We made three consecutive research studies on the characteristics of corporate governance in Slovenia in the period 1998 to 2006. We compare the results of our studies made in 1998 and 2002 with the latest results in 2006. The most important long-term strategic objective of Slovenian companies is growth. The share of Slovenian companies not considering equity opportunity costs has decreased significantly in the last six years due to the consolidation of ownership structures. The controlling owners are more active in setting the required rate of return on their equity investments. There is no conflict of interests between internal and external shareholders in most companies. Obviously, Slovenian companies have changed their strategic behaviour to reflect the interests of their stakeholders. We may argue that some stakeholders, like customers and employees, are even more important for Slovenian managers than the owners.
\end{abstract}

\section{INTRODUCTION}

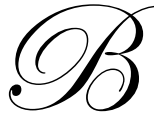

y the term social responsibility we understand the obligation of organization management to make decisions and take actions that will enhance the welfare and interests of society as well as the organization. One reason for the difficulty to understanding social responsibility is that managers must confront the question $»$ responsibility to whom $\ll$ ? From a social responsibility perspective, enlightened organizations view the internal and external environment as a variety of stakeholders (Daft, Marcis, 2001, p.118). The Effective corporate governance ensures that long-term strategic objectives and plans are established, and that the proper management and management structure are in place to achieve those objectives, while at the same time making sure the structure functions to maintain the corporation's integrity, reputation, and accountability to its relevant constituencies. In recent times, more than half of the states in the US have passed stakeholders laws, which permit or even require directors to consider the impact of their actions on constituencies other than shareholders, including the employees, customers, suppliers, and the community. This is in contrast to the traditional model of publicly held corporation which says that corporate directors serve only one constituency - their shareholders (Monks, Minow, 2001, p.37).

Our paper offers some insights into the characteristics of the corporate governance system in Slovenia. We made three consecutive research studies on the characteristics of corporate governance in Slovenia in the period 1998 to 2006. We compare the results of our studies made in 1998 and 2002 with the latest results in 2006. Our empirical research was based on a fully-structured interview that was prepared with pre-coded responses. A firm had to have specific characteristics to fall within the research sample: 
1. it should have had at least 250 employees;

2. it should have had at least USD 5 million in annual income; and

3. it should have been a joint-stock company.

This study is based on a research sample of 69 companies that met these criteria.

In order to determine the dynamic of the strategic behaviour of managers in the last eight years we compare the top managers' values in our research 2006 with the research made by Kalacun in 2000. The results of the three longitudinal studies regarding investment decisions of managers in the years 1998, 2002 and 2006 have been compared. We try to determine the most important characteristics of the strategic behaviour of managers in Slovenia in the last period of transition and the changing pattern of corporate governance in Slovenia.

\section{THEORETICAL BACKGROUND}

A corporation is a mechanism established to allow different parties to contribute capital, expertise, and labour for the maximum benefit of all of them. Corporation offer lasting and resilient social structure (Monks, Minow, 2001, p. 11). In order to qualify as a moral agent, a corporation would need to embody a process of moral decision making. The perennial question is whether business can do well by doing good (Donaldson, 1982, p.30). Some companies have made the social responsibility part of their marketing strategy. Consumers can feel less guilty about buying arguably decadent products if they know that by doing so they are supporting good causes. At one end of the scale are the most basic aspects of social responsibility, like compliance with the law. At the other end of the scale are activities so unrelated to the goods and services sold that pursuing them is considered by the marketplace to be irrelevant to the company's productivity.

Proponents of corporate social responsibility have used four arguments to make their case: moral obligation, sustainability, license to operate, and reputation (Porter, 2004, p. 81). However studies of the effect of a company's social reputation on consumer purchasing preferences or on stock market performance have been inconclusive at best. Having no way to quantify the benefits of these investments puts corporate social responsibility programs on shaky ground, liable to be dislodged by a change of management or a swing in the business cycle.

In practice, it is possible to distinguish between three levels of company responsibility. The primary level comprises the company's responsibilities to meet its material obligations to shareholders, employees, customers, suppliers and creditors, to pay its taxes and to meet its statutory duties. The sanctions against failure to match up to these relatively easy defined and measured responsibilities are provided by competition and the law. The next level of responsibility is concerned with the direct results of the actions of companies in carrying out their primary task and includes making the most of the community's human resources and avoiding damage to the environment. Beyond these two levels, there is a much less well defined area of responsibility, which takes in the interaction between business and society in a wider sense. On this level it is a question how far has business a responsibility to maintain the framework of the society in which it operates and how far should business reflect society's priorities rather than its own commercial one. Some other authors also tried to develop a model for evaluating social performance of companies (see Figure 1). 
Figure 1: Model for evaluating corporate social performance

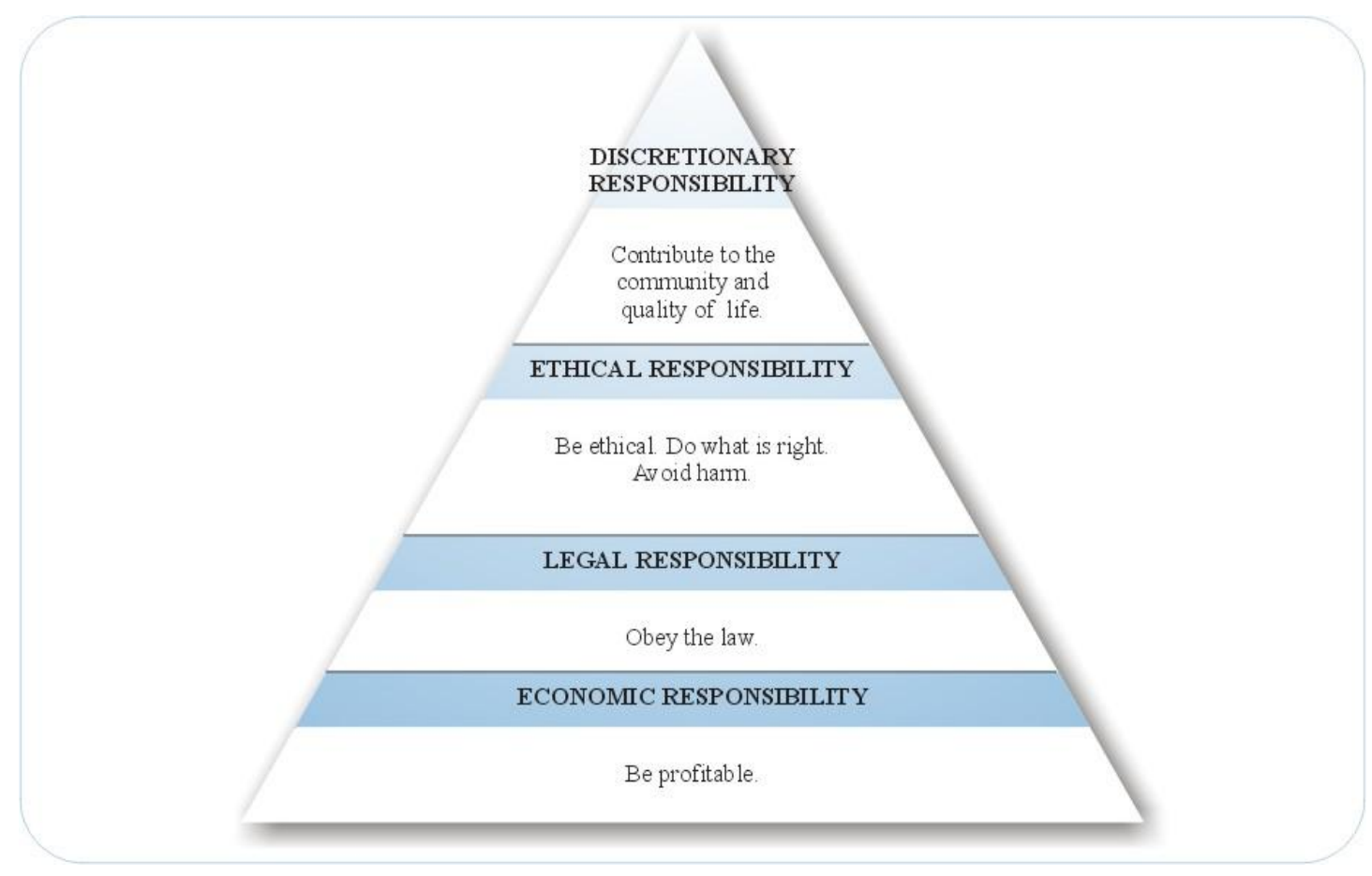

Source: Archie B. Carroll: The Pyramid of Corporate Social Responsibility: Toward the Moral Management of Corporate Stakeholders, Business Horizons, 34 (July-August) 1991. Daft R., Marcic D.: Understanding Management, 2001 , p. 122.

Among the key findings of a SIRAN analysis of the reporting practices companies in the S\&P 100 INDEX (www.socialinvest.org):

- $\quad$ More than half of the S\&P 100 Index (58 companies) have special sections of their websites dedicated to sharing information about their social and environmental policies and performance.

- $\quad$ Almost 40 percent of the S\&P 100 Index (39 companies) now issue annual corporate social responsibility reports.

- $24 \%$ of companies of the S\&P 100 Index say they base their corporate social responsibility reports on the widely recognized external standard provided by the Global Reporting Initiative's Sustainability Reporting Guidelines. 20\% of companies included an index to Global Reporting Initiative indicators in their reports. $6 \%$ of companies met the highest standard of reporting fully in accordance with the Global Reporting Initiative guidelines.

- $\quad$ Of those companies issuing annual Corporate Social Responsibility reports, $62 \%$ say their reports are based on Global Reporting Initiative standards, and 51\% include an index to Global Reporting Initiative indicators.

The basis of a corporation's existence is wealth maximization. There is no such thing as a good corporation that is not completely profitable. Corporations live in a world where the market determines what people will buy and what they will pay. A corporation that does not produce goods that people want at a price they are willing to pay has no reason to exist. On the other hand we want the corporation to work wit us to keep the workplace and the environment safe. We want a continual sense of progress and growth from our corporations. We want our interest in the company whether as shareholder, employee, customer, supplier, creditor or just neighbor to be designed for the long run. Moreover, managers should take care to satisfy the interests of their primary stakeholders. In theory, corporations support the free market, with as little interference from government as possible. In reality, whenever 
corporations can persuade the government to protect them from the free market, by legislating barriers to competition or limiting their ability, they do so. In practice, corporations have influenced government at least as much as government has influenced business (Monks, Minow, 2001, p. 16). Shareholders expect managers to run their business in a way that will encourage a supportive governmental and societal climate to capitalist enterprise.

The property-based concept of the firm has prevailed in the Anglo-Saxon world. The Chicago School of Law and Economics treats the company as a nexus of contracts through which the stakeholders regulate transactions between each other. In this theory, the company's assets are the property of the shareholders, and managers are viewed as agents of the shareholders with all of the enforcement difficulties associated with agency relationships, but without legal obligations to any other stakeholder. This view maintains that the rights of creditors, employees and others are strictly limited to statutory, contractual and common law rights (Allen, 1992). Any broadening of a company's social obligations was dangerous, according to this school of thought (Clarke, 1997, p. 185). Milton Friedman once said: »Few trends could so thoroughly undermine the foundations of our free society as the acceptance by corporate officials of a social responsibility other than to make as much money for their shareholders as possible « (1962, p. 113). Hayek added that, once the management of a corporation is regarded as not only being entitled but even obliged to consider in its decisions whatever is regarded as being of a social interest, it gains uncontrollable power. In this case, managers would become the subject of the public interest (1979, p. 79). These views expressed by neo-liberal economists strongly influenced the corporate governance system of the Anglo-Saxon world in the 1970s and 1980s. Managers were mostly oriented to short-term financial objectives such as sustaining the share price and dividend payments at all costs. We can identify a substantial numbers of mergers and acquisitions in this period that were pursued to discipline managers. Monks and Minow (2001, p. 81) attempted to restate the essential principles of the shareholder theory of the firm. Their approach allows all other interests to be factored in without losing sight of the goal of long-term wealth maximisation. It is difficult enough to determine the performance of a company's strategy based on just one goal, namely shareholder value. It is impossible when we add in other goals. Therefore, the only way to determine a company's performance is to consider the long-term shareholder value (Clarke, 1997, p. 186).

The modern corporation typically has multiple owners who each intend to maximise their investment in the corporation. Owners become principals when they contract with executives to manage their firms on their behalf. Thus, in the modern corporation agents and principals are motivated by opportunities for their own personal gain. Principals invest their wealth in companies and design the corporate governance mechanism in ways that maximise their utility. The chance that agents do not share the same interests and utility choices as their principals is substantial (Davis et al., 1997, p. 22). According to the agency theory, it is difficult for principals to determine exante which agents will self-aggrandise and so it is prudent for principals to limit potential losses to their utility (Williamson, 1985).

Some management studies have suggested that managers make different decisions when owners are actively involved in the firm (owner-controlled) versus the situation where paid managers are relatively free to set the firm's strategy (Tosi, Katz, Gomez, 1997; McEachern, 1975). Thus, firms become controlled by managers when the firm's shares are so disparately owned that no single shareholder is able to effectively guide the decisions of managers. The objective in agency theory is to reduce the agency costs incurred by principals by imposing internal controls to keep the agent's self-serving behaviour in check. There are various internal and external (acquisitions, divestitures) corporate governance control mechanisms to prevent the agency problem. Two corporate governance mechanisms that have attracted substantial attention in the literature are alternative executive compensation schemes and governance structures.

An alternative view is the stakeholder theory of the firm. The philosophical antecedents of stakeholder theory date back to the 19th century, to the conception of co-operative movement and mutuality. In »The Theory of the Growth of the Firm «, Edith Penrose laid the intellectual foundations for stakeholder theory in her concept of the company as a bundle of human assets and relationships. In his work, Clark thoroughly described the development of the stakeholder theory approach (1997, pp. 186-187). Hill and Jones (1992) expanded the standard principal-agent paradigm to the stakeholder agency problem. In this view, managers can be seen as the agents of all stakeholders. With the onset of knowledge-based competition (Buckley, Carter, 2000, pp. 55-71; Teece, 2000, pp. 35-54), this 
approach will be even more important in the near future. If knowledge is a predominant productive resource and most knowledge is created by and stored within individuals, then employees are also the primary stakeholders (Grant, 1997). The stakeholder theory approach has been applied to performance management theory. The growing emphasis is on customer relationship management, employee relationships, supplier relationships, the relations with investors and with the local community. Some well-known approaches such as the European Foundation for Quality Management or Balanced Scorecard system try to cover performance in all key relationships (Kaplan, Norton, 1996; European Foundations for Quality Management, 1993). The fundamental issue is how to satisfy the interests of more complex constituencies than shareholder theory might suggest.

Traditional theory of the firm argues that the arguments advancing a constituency for corporate functioning are miscast. It is difficult enough to determine the success of a company's strategy based on only one goal shareholder value. It is impossible when we add in other goals. The only way to evaluate the success of a company's performance is to consult those who have the most direct and wide-reaching interest in the results of that performance - the shareholders. Only owners have the motive to inform themselves and to enforce standards that arguably are a proxy for the public interest (Monks, Minow, 2001, p. 40).

\section{THE RESULTS OF OUR STUDY}

Internal owners control the majority-voting share in $34 \%$ of the companies (see Figure 2). The share of the state has been decreased in last eight years, however it's still higher as it is in other EU member states.

Figure 2: The most influential stakeholder in the process of corporate governance

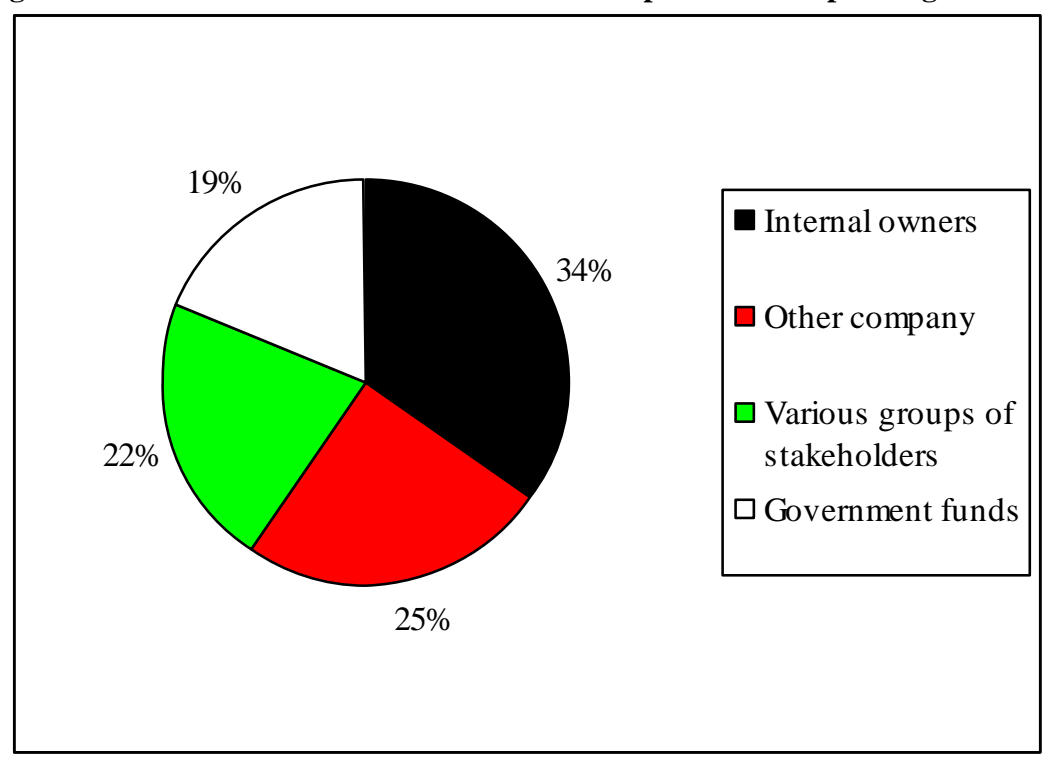

In the first period of transition 1991-1998, the consolidation of business activities has been the most important strategic priority. On the other hand growth has been the most important long-term strategic objective of Slovenian companies for last eight years (see Figure 3). Creating value for shareholders is the most important longterm strategic objective in a relatively small number of companies. This finding could be problematic from the agency problem point of view if the company is in a mature or even a declining industry. Jensen argued that the likelihood of the agency problem occurring is considerably greater in a declining industry. Instead of developing a consolidation strategy, managers are in many cases still oriented towards growth (1988, page 46). On the other hand, we are faced with a convergence of interests if an industry is growing. In such a case, the opportunities for growth within that industry usually also result in the maximisation of shareholder value. No company in our research sample would formulate the maximisation of employees' income as the key strategic objective. As already pointed 
out, the most important strategic objectives are not necessarily mutually exclusive. However, they somehow do show the strategic priorities on one hand and the influence on the corporate governance process of the stakeholders on the other.

Figure 3: The most important long-term strategic objective

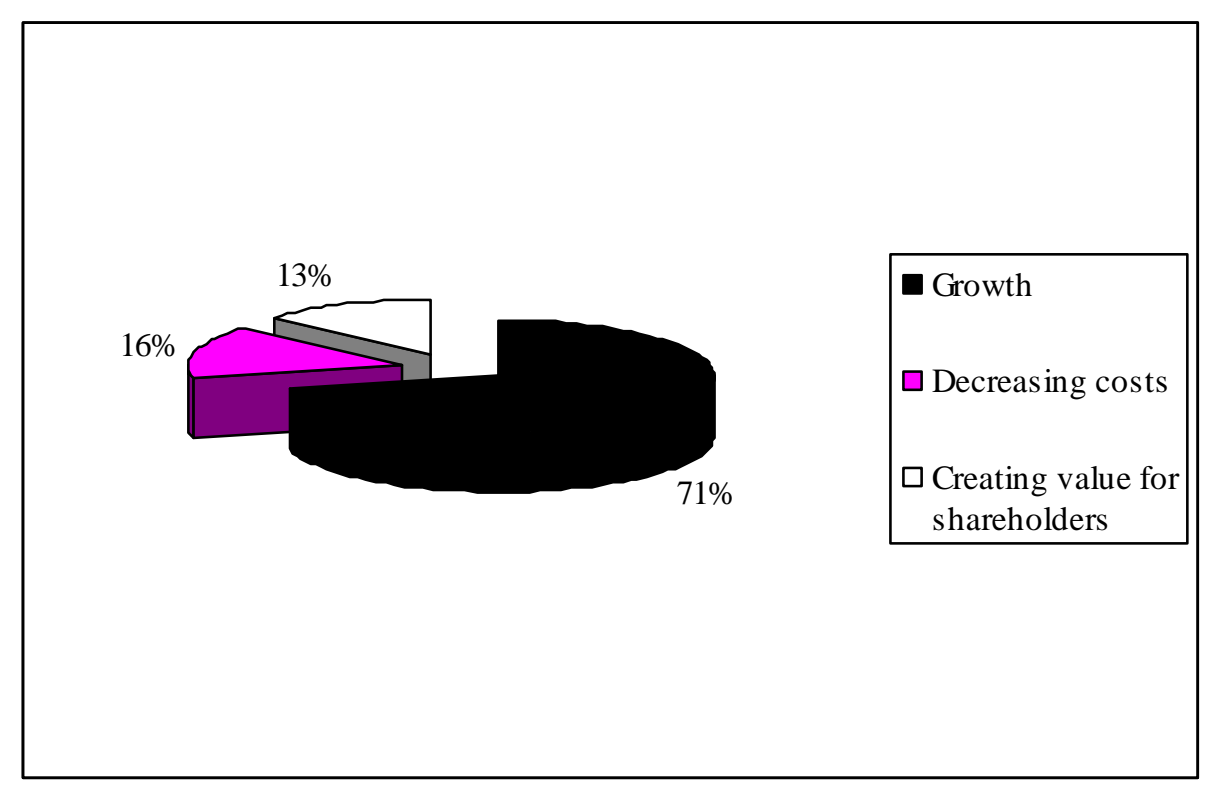

In order to create value for shareholders managers should consider the concept of »EVA « (economic value added concept) (Miller, Dess, 1996, page 122). One problem of using traditional financial accounting information to measure profitability is that it does not take into account the opportunity cost of equity capital. We care about financial returns because of their importance to owners as a stakeholder group, so overlooking the owners' investment costs leads to a serious oversight (McCrory, Gerstberger, 1992, page 33-38). Equity is often a very expensive source of capital and ignoring it misrepresents the amount of economic value the business is creating for the shareholders. Controlling owners are more active in setting the required rate of return on their equity investments. In over one-third of companies, managers assumed that in 2002 the opportunity cost on equity investment is $10 \%$, which was higher than the cost of long-term debt. The share of such companies decreased in 2006 due to the decreasing interest rates (see Figure 4).

In our research that was conducted in 2006 we found out that managers in $42.1 \%$ of companies, when valuing an investment opportunity, do not consider the opportunity costs of equity capital or assume that such cost is zero. In our previous research conducted in Slovenian companies in 1998, the percentage share of these companies was far greater $(90.5 \%)$. The share of Slovenian companies that do not consider equity opportunity costs has dropped significantly in the last eight years due to the consolidation process of ownership structures (see Figure 5). 
Figure 4: The opportunity cost of equity investment considered by managers when calculating the weighted average costs of capital

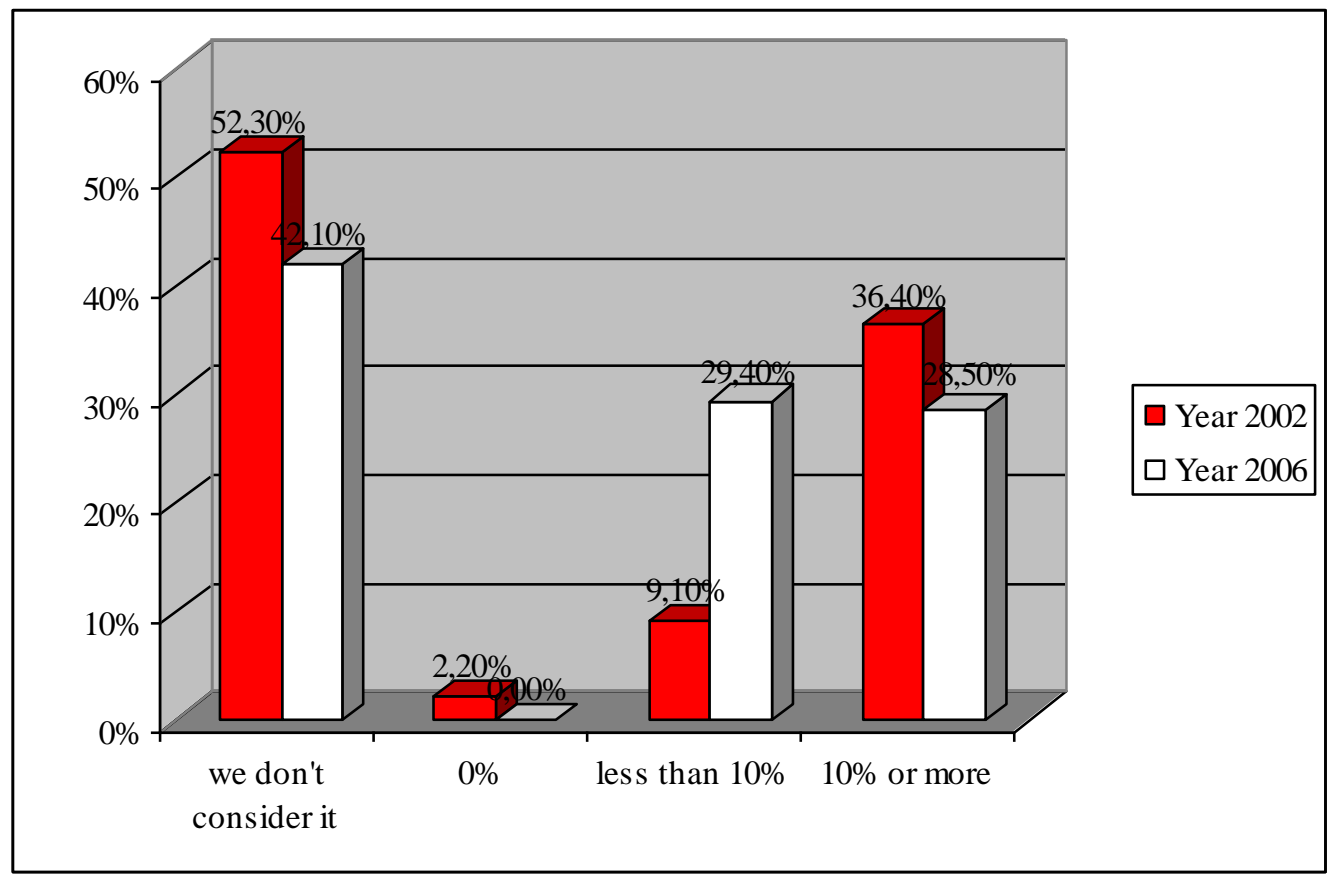

Figure 5: Managers who not consider the equity opportunity costs

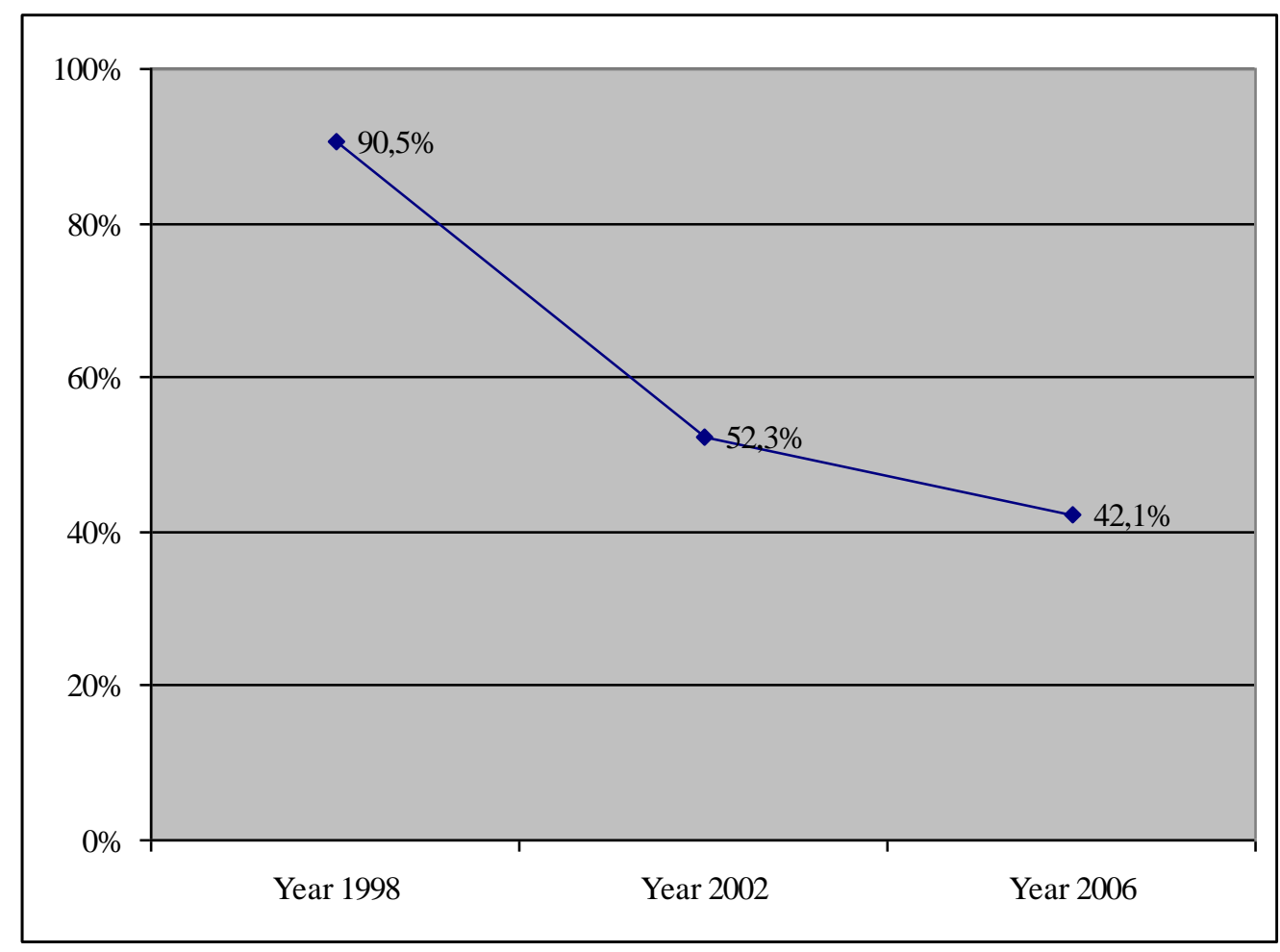


Managers and internal owners have managed to forge specific coalitions in many companies that are controlled by insiders. These companies are in fact controlled by managers and they behave differently to companies controlled by strategic outside investors. An insider-dominated firm may generate neither the resources needed for restructuring activities, such as investment, nor have the incentive to sell the firm to outsiders who have those resources (Blanchard, Anghion, 1995). Prašnikar and Svejnar (1998, page 19) found some strong arguments in their research to support this thesis regarding the role of insiders in Slovenian companies. For example, in the cases of some takeover bids managers and the internal owners forged a specific coalition because they were afraid of losing their jobs. In such a case, the takeover bid failed even though it would have enhanced the competitive position of merged company in the market. However, the fear of reorganisation and losing jobs due to the sharing of activities between companies prevailed and there was no reselling of shares by internal owners to strategic outsiders.

In our last research in the year 2006 we found out that the most important value of the managers in Slovenia is growth and development of their companies (4.51), followed by customers' satisfaction (4.49) and employees' satisfaction (4.38). Profit maximisation (3.93) and shareholder value (3.84) are surprisingly less important as well as the ecological issues (3.81). By comparing our results with the earlier research made by Kalacun in 2000, we found out that the managers in Slovenia have stable values (see Figure 6). Kalacun found in her research (2000, page 23) that the most important values of Slovenian managers are the following: growth and development of the company (4.59), customers' satisfaction (4.47), employees' satisfaction (4.41) and ecological issues (4.03). Therefore, we may argue that some stakeholders, like customers and employees, are even more important for Slovenian managers than the owners.

Figure 6: The most important values of Slovenian managers

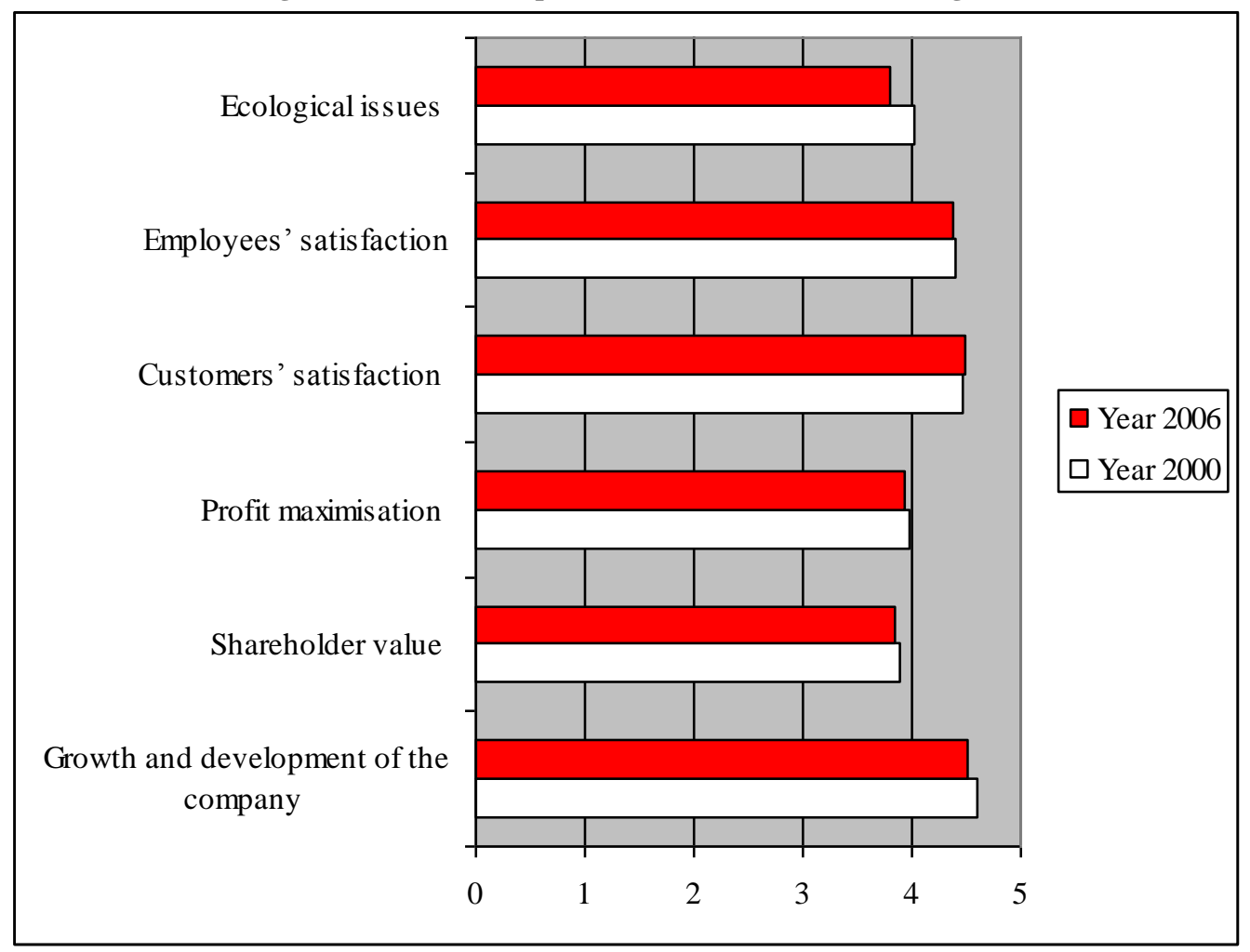

Scale: 1- not at all important, 5- very important 


\section{CONCLUSION}

Studies of the effect of a company's social reputation on consumer purchasing preferences or on stock market performance have been inconclusive at best. From a social responsibility perspective, enlightened organizations view the internal and external environment as a variety of stakeholders. Slovenian companies have changed their strategic behaviour to reflect the interests of their stakeholders. According to our research we may argue that some stakeholders, like customers and employees, are even more important for Slovenian managers than the owners. The most important long-term strategic objective of Slovenian companies is growth and development. On one hand the share of Slovenian companies not considering equity opportunity costs has decreased significantly in the last eight years due to the consolidation of ownership structures. The controlling owners are more active in setting the required rate of return on their equity investments. On the other hand customers have a significant impact on the strategic decisions of the companies involved in our research. This is very positive and reflects a long-term strategic partnership between companies and their key customers. According to the results of our studies that have been conducted in last few years we can argue that the stakeholder theory is the leading corporate governance approach in Slovenia. The growing emphasis is on customer relationship management, employee relationships and supplier relationships as well as the partnership with the local community.

\section{REFERENCES}

1. Aghion, P. and Carlin, W. (1997), Restructuring outcomes and the evolution of ownership patterns in Central and Eastern Europe, Lessons from the economic transition, Kluwer Academic Publishers, Dordrecht.

2. Allen, W. T. (1992), Our Schizophrenic Conception of the Business Corporation, Cardozo Law Review, Vol. 14 (2), 261-282.

3. Blanchard, O. and Aghion, P. (1995), On Insider Privatisation, MIT press, Boston.

4. Buckley, J. P. and Carter J. M. (2000), Knowledge Management in Global Technology Markets, Long Range Planning, Vol. 33 (1), 55-71.

5. Carroll, B. Archie (1991), The Pyramid of Corporate Social Responsibility: Toward the Moral Management of Corporate Stakeholders, Business Horizons, Vol. 34 (July-August).

6. Clark, T. (1998), The Stakeholder Corporation: A Business Philosophy for the Information Age, Long Range Planning, Vol. 31 (2), 182-194.

7. Daft, R., Marcic, D. (2001), Understanding Management, Thomson Learning, London.

8. Davis, H. J., Schoorman, F. D. and Donaldson L. (1997), Toward a Stewardship Theory of Management, Academy of Management Review, Vol. 22 (1), 20-47.

9. Donaldson, L. and Davis J. H. (1991), Stewardship theory or agency theory: CEO governance and shareholder returns. Australian Journal of Management, Vol. 16, 49-61.

10. European Foundation for Quality Management (1993), The European Quality Award Application, Brochure.

11. Friedman, M. (1962), Capitalism and Freedom, University of Chicago Press, Chicago.

12. Grant, R. M. (1997), The Knowledged Based View of the Firm: Implications for Management Practice, Long Range Planning, Vol. 30 (3), 450-454.

13. Hayek, F. A. (1979), The Political Order of a Free People, Law, Legislation, Liberty, Vol. 3., 81-85.

14. Hill, C. W. and Jones, T. M. (1992), Stakeholder Agency Theory, Journal of Management Studies, Vol. 29, 131-154.

15. Jensen, C. M. (1988), Takeovers, Their Causes and Consequences, Journal of Economic Perspectives, Vol. 2 (1), 21-48.

16. Kalacun, S., (2000), Poslovna etika v slovenskem poslovnem prostoru, Diplomsko delo, Ekonomska fakulteta v Ljubljani, Ljubljana.

17. Kaplan, R. S. and Norton, D. P. (1996), The Balanced Scorecard, Harvard Business School Press, Boston.

18. Katz, P. J. and Niehoff, P. B. (1998), How Owners Influence Strategy - A comparison of Owner-Controlled and Manager-Controlled Firms, Long Range Planning, Vol. 31 (5), 755-761.

19. McEachern, W. (1975), Managerial Control and Performance, Lexington Books, Lexington. 
20. McCrory, F. W. and Gerstberger P. (1992), The New Math of Performance Measurement, Journal of Business Strategy, March-April, 33-38.

21. Miller, A. and Dess, D. G. (1996), Strategic Management (Second Edition), The Mc Graw-Hill, New York.

22. Monks, R. A. G. and Minnow, N. (2001), Corporate Governance, Second Edition, Blackwell, Oxford.

23. Penrose, E. (1959), The Theory of the Growth of the Firm, Oxford University Press, Oxford.

24. Porter, M. (2004), Strategy and Society, Harvard Business Review, Vol. 82 (5), 80-92.

25. Prašnikar, J. and Svejnar, J. (1998), Investment, Wages and Ownership during the Transition to a Market Economy: Evidence from Slovenian Firms, Working Papers Series, No. 79, Department of Economics, Ljubljana.

26. Teece, D. J. (2000), Strategies for Managing Knowledge Assets: the Role of Firm Structure and Industrial Context, Long Range Planning, Vol. 33 (1), 35-54.

27. Tosi, H., Katz, J. and Gomez, L. M. (1997), Disaggregating the agency contract: The effects of monitoring, incentive alignment, and term in office on agent decision making, Academy of Management Journal, No. 3, 584-602.

28. Weston, J. F., Chung, S. K. and Hoag, E. S. (1990), Mergers, Restructuring and Corporate Control, Prentice-Hall, New Jersey.

29. Williamson, O. E. (1985), The economic institutions of capitalism: Firms, markets, relational contracting, Free Press, New York.

30. http//:www.socialinvest.org: Socially Responsible Investment Analysts Find More Large U.S. Companies Reporting On Social and Environmental Issues.

\section{NOTES}

